\title{
Study on Radon Concentration in ground water and Physicochemical parameters of Tumkur industrial areas, Karnataka State, India
}

\author{
S.R ${ }^{1^{*}}$. Nagabhushana, Srinivasa $E^{2}$, Suresh $S^{3}$, Sannappa $\mathbf{J}^{3}$ \\ ${ }^{1 *}$ Department of Physics, Government First Grade College Tiptur, Karnataka, India-572201 \\ ${ }^{2}$ Department of Physics, IDSG Government Degree College, Chikmagalur, India-577102 \\ ${ }^{3}$ Department of Physics, Kuvempu University, Shankaraghatta, India-577451 \\ *Corresponding Author: e-mail:srnbhushan@gmail.com, Mob: +919845284949
}

Available online at: www.isroset.org

Received: 19/Mar/2019, Accepted: 13/Apr/2019, Online: 30/Apr/2019

\begin{abstract}
The concentration of radon in the ground water around Tumkur industrial areas namely Hirehalli, Antharasanahalli, Satyamangala, and Vasanthanarasapura were measured by emanometry technique. The activity of primordial radionuclides such as Radium $\left({ }^{226} \mathrm{Ra}\right)$, Thorium $\left({ }^{232} \mathrm{Th}\right)$ and Potassium $\left({ }^{40} \mathrm{~K}\right)$ in different rock samples of the study area were estimated by HPGe detector based on gamma ray spectrometry. Standard methods have been applied to estimate the physicochemical parameters of the samples. The average value of radon concentration varies from $5.61 \mathrm{Bql}^{-1}$ to $160.50 \mathrm{Bql}^{-1}$ with an average value of $75.40 \mathrm{Bql}^{-1}$. The total effective dose received by workers and publics due to radon inhalation and ingestion varies from $15.32 \mu \mathrm{Svy}^{-1}$ to $438.20 \mu \mathrm{Svy}^{-1}$ with an average value of $205.84 \mu \mathrm{Svy}^{-1}$. The average value of primordial radio nuclides such as ${ }^{226} \mathrm{Ra},{ }^{232} \mathrm{Th}$ and ${ }^{40} \mathrm{~K}$ in the rock samples of the study area varies from $20 \pm 1.5$ to $150 \pm 3 \mathrm{Bqkg}^{-1}, 25 \pm 0.4$ to $200 \pm 2.5 \mathrm{Bqkg}^{-1}$ and $450 \pm 4$ to $1800 \pm 15 \mathrm{Bqkg}^{-1}$ respectively and their corresponding mean values are $65.6 \pm 1.3 \mathrm{Bqkg}^{-1}, 81.8 \pm 1.5 \mathrm{Bqkg}^{-1}, \mathrm{and}^{-1}$ $854.2 \pm 12 \mathrm{Bqkg}^{-1}$ respectively. These values are comparable with global average. The average values of Physico chemical parameter are within the safe level as prescribed by USEPA and WHO. The results shows noteworthy correlation cannot be observed between concentration of radon and physicochemical parameters in water samples in the study area. The radon concentration in ground water mainly depends on the type of aquifers and its mineral compositions.
\end{abstract}

Keywords: Radon concentration; activity of primordial nuclides; types of aquifers; physicochemical parameters; Total dose.

\section{INTRODUCTION}

Ground water is precious, vital, wide spread and pure form available in nature. It is available only $2.4 \%$ out $71 \%$ of total volume of surface water available on earth. In India maximum rural and urban population depends on ground water for drinking purposes. There is a great demand for pure water because the ground water and surface water are highly polluted due to rapid urbanization and industrialization [1]. The good quality of ground water is very important to maintain the good health of human beings and other living things. The government of Karnataka has developed large industrial areas around Tumkur city is situated $70 \mathrm{Km}$ from Bengaluru, the IT capital of India. Hirehalli, Sathyamangala, Antharasanahalli and Vasanthanarasapura are the industrial areas developed around Tumkur. Vasanthanarasapura is one of the major industrial hub developed as part of Chennai-Bengaluru industrial corridor project and other three are Hirehalli, Antharasanahalli and Satyamangala. These industrial areas were selected for the study because 196341 laborers are working in 28179 industries in shift wise basis. Different industries such as granite crushing and polishing industries, paint industries, rice mills, chemical industries and other type of industries are working. These industries discharge liquid effluents without any proper treatment into nearby open pits. And also leave the effluents to pass through unlined channels [2]. The solid industrial waste produced by these industries are collected and dumped at Ajjagondanahalli village which is $2-3 \mathrm{~km}$ from Vasanthanarasapura industrial area. This industrial waste discharges the pollutants into the atmosphere. The various pollutants are dissolved in water due to the interaction with the industrial waste. Due to this, the ground water may changes the characteristics and Physico chemical parameters. The workers and public living in and around the industrial areas mainly depends on the ground water for drinking purposes. In view of this above facts we are selecting the industrial area for the study. The ground water 
contains physicochemical parameters, mineral compositions, radionuclides such as ${ }^{238} \mathrm{U},{ }^{232} \mathrm{Th},{ }^{226} \mathrm{Ra}$ and ${ }^{222} \mathrm{Rn}$ [3]. Radon is a radioactive inert gas of half-life 3.82 days. Radon is obtained during the decay of ${ }^{226} \mathrm{Ra}$ which is produced by decay of ${ }^{238} \mathrm{U}$. Both ${ }^{222} \mathrm{Rn}$ and ${ }^{226} \mathrm{Ra}$ are water soluble, and their solubility depends on the temperature. The solubility decreases with the increase in temperature. The concentration of radon in ground water is mainly depends on activity of ${ }^{226} \mathrm{Ra}$ present in the aquifers. It is also influenced by mechanisms such as precipitation, dissociation, complexation, adsorption-desorption which effects the transport of radium and radon in water [4]. These processes are related to the chemical composition of the ground water. The study of radon in atmosphere and ground water is very important because among all the natural sources of radiation, the highest radiation dose is contributed by radon to publics. Radon is a carcinogenic, as per the epidemiological studies radon is the second highest contributor for lung cancer [5,6 ]. The potential health risk associated with radon and other naturally occurring radioactive elements present in water have raised the relevance to study [7]. It can cause the radiation exposure through inhalation and ingestion and produce serious health risk [8]. The organ at most risk from radon dissolved in water is stomach. When radon or its progeny are inhaled, lung cancer accounts for most of total incremental cancer risk [9]. Ingestion of radon present in water is suspected of associated with tumors in internal organs of human beings mainly in stomach and kidney [10]. According to the reports of WHO the breathing of radon released by water contributes $89 \%$ of lung cancer and $11 \%$ of stomach cancer are caused by drinking water [11].The higher concentration of Physico chemical parameters in drinking water leads to several health problems such as water borne diseases, fluorosis, thyroid, premature baby, cholera and other physiological problems [5].

In view of this importance the present study is very essential to understand the dependence of radon concentration on the types of bed rocks, to draw the relationship between radon and physicochemical parameters and to calculate dose due to radon to the publics and workers of the study area. Also to establish the factors which may control the presence of radon in ground water.

\section{MATERIALS AND METHODS}

\subsection{Measurement of Radon concentration in water}

${ }^{222} \mathrm{Rn}$ concentration in ground water was measured by the Emanometry method using Radon bubbler (Fig. 1) [12-13]. Hand pump and Bore well water samples were collected from sixteen different selected locations in and around four industrial areas of Tumkur. Fresh water samples are collected from Bore well by allowing water to run for four to eight minutes. Air tight plastic bottles of volume $500 \mathrm{ml}$ are used to collect water samples. Water is filled in plastic bottles such that zero head space is maintained. Water samples are analyzed in the laboratory as early as possible. By the method of vacuum transfer technique water sample of volume $60 \mathrm{ml}$ of is poured to bubbler. Radon dissolved in water was transported into pre-evacuated scintillation cell. This cell was kept aside for three hours without any disturbance bring radon to equilibrium with its daughter products. Now it was coupled with photomultiplier and alpha counting system. The concentration of radon in the water samples were estimated by below relation [12].

$R n^{222}\left(B q \cdot l^{-1}\right)=\frac{6.97 \times 10^{-2} \times D}{E \times V \times\left(1-e^{-\hat{\lambda} t}\right) \times e^{-\lambda T}}$

Wher

e, $D$ is Counts above background. $V$ is Volume of water used. $E$ is Efficiency of the scintillation cell (74\%). $\Lambda$ is Decay constant of radon $\left(2.098 \times 10^{-6} \mathrm{~s}^{-1}\right)$. $T$ is Counting delay after sampling. $\mathrm{t}$ is Counting $(s)$.

\subsection{Measurement of dose due to in water}

Dose received due to presence of radon in water is classified into two categories. They are dose due to inhalation and ingestion. Amount of water consumed in a day is the major important factor to measure effective dose due to ingestion in human beings. Radon present in drinking water escapes to indoor air during domestic activities like showering, washing etc. when this escaped radon is inhaled it can cause lung cancer [14]. Waterborne radon is considered as highest contributor of radiation dose to publics than any other contaminants in water [15]. The inhalation dose to human beings by radon in water was calculated following relation [5],

$D_{\text {In }}\left(\mu S v y^{-1}\right)=C R_{n} W \times R_{n} W \times I \times D C F$

Where, $D_{\text {in }}$ is inhalation effective dose. $C R_{n} W$ is concentration of radon in water $\left(\mathrm{Bq} \mathrm{l}^{-1}\right) . R_{n} W$ is the radon in air to the radon in water $\left(10^{-4}\right) . F$ is theradon and its progenies equilibrium factor (0.4). $I$ is average indoor occupancy time per individual $\left(7000 \mathrm{ha}^{-1}\right)$. DCF is the dose conversion factor for radon exposure $\left(9 \mathrm{nSv}\left(\mathrm{Bqhm}^{-3}\right)^{-1}\right)$.

Ingestion dose due to radon present water samples have been estimated by using the relation [5].

$D_{I g}\left(\mu S v y^{-1}\right)=C R n W \times C_{W} \times E D C$

Where, $D_{I g}$ is the effective dose for ingestion. $C R n W$ is the radon concentration in water $\left(\mathrm{Bq} \cdot \mathrm{l}^{-1}\right) . C_{w}$ is the weighed estimate of water consumption $\left(60 \mathrm{La}^{-1}\right) . E D C$ is the effective dose coefficient for ingestion (3.5 $\left.\mathrm{nSvBq}^{-1}\right)$. Multiplying ingestion and inhalation doses by tissue weighting factor for stomach and lungs, dose contribution to respective organs were calculated [16]. 


\subsection{Measurement of activity of ${ }^{226} \mathrm{Ra},{ }^{232} \mathrm{Th}$ and ${ }^{40} \mathrm{~K}$.}

Natural radioactivity in rock samples are done by collecting $2 \mathrm{~kg}$ of rock of different locations of study area. These samples were dried directly in sun light. Unwanted materials present in the samples are separated. Then powdered by crushing and sieved thorough $150 \mu \mathrm{m}$ size sieve. The powdered rock samples were dried using oven at $110^{\circ} \mathrm{C}$ temperature to remove moisture and unwanted things for 24hours. Then samples are kept for 30days in $250 \mathrm{ml}$ air tight polythene containers. During this period radium and their daughter products come to secular equilibrium. Then samples are analyzed with gamma ray spectroscopy. Activity of ${ }^{226} \mathrm{Ra},{ }^{232} \mathrm{Th}$ and ${ }^{40} \mathrm{~K}$ are measured in soil samples by following standard gamma spectrometric procedure [17]. ${ }^{226} \mathrm{Ra},{ }^{232} \mathrm{Th}$ and ${ }^{40} \mathrm{~K}$ concentrations were measured by HPGe detector. This detector is based with gamma ray spectrometer and having efficiency $41 \%$. It is n-type detector designed and manufactured by Canberra Industries, Inc. It is coupled to a DSA- 1000 with $16 \mathrm{~K}$ Multi Channel Analyzer. Lead shield of thickness $0.1-\mathrm{m}$ is covered on the detector. Recording the background counts and applying Compton corrections to concentration of ${ }^{226} \mathrm{Ra},{ }^{232} \mathrm{Th}$ and ${ }^{40} \mathrm{~K}$ was estimated by peaks of ${ }^{214} \mathrm{Bi}(609.3,1129.3$ and $1764.5 \mathrm{keV}) .{ }^{228} \mathrm{Ac}(911.2 \mathrm{keV})$ and ${ }^{208} \mathrm{TI}(1460.8 \mathrm{keV})$ respectively. IAEA quality assurance reference materials: RG U-238, RG Th-232 and RG K-40 are used for efficiency calibration of the detector. Minimum detection levels (MDL) for ${ }^{226} \mathrm{Ra},{ }^{232} \mathrm{Th}$ and ${ }^{40} \mathrm{~K}$ is $0.9,1.2$, and $4.0 \mathrm{~Bq} \mathrm{~kg}{ }^{-1}$ respectively. The counting time is 60000 s. The activity concentration of radionuclides (in $\mathrm{Bq} \mathrm{kg}^{-1}$ ) was calculated using the following relation.

\section{Activity $\left(\mathrm{Bqkg}^{-1}\right)=\frac{(s \pm \sigma) X 100 X 1000 X 100}{E W A}$}

Where, $\mathrm{s}$ is counts per second. $\sigma$ is standard deviation of $\mathrm{s}$. E is efficiency of counting (\%). A is abundance of gamma (\%) of the radionuclides. W is mass of rock sample $(\mathrm{kg})$.

\section{RESULTS AND DISCUSSION}

Emanometry technique was applied to measure radon concentration in drinking water. The activity of primordial radionuclides was estimated by HPGe detector based gamma ray spectrometer. The measured mean values of concentration of radon and total annual effective dose, inhalation dose and ingestion dose due to radon were summarized in the Table1. The overall average value of concentration of radon in the present study area ranges from $5.61 \mathrm{Bql}^{-1}$ to $160.50 \mathrm{Bql}^{-1}$ with mean value of $67.54 \mathrm{Bql}^{-1}$. The inhalation, ingestion and total effective dose due to the radon in water to the public of the study area varies from $14.14 \mu \mathrm{Svy}^{-1}$ to $404.50 \mu \mathrm{Svy}^{-1}$ with a mean value of 190 $\mu \mathrm{Svy}^{-1}, 1.18 \mu \mathrm{Svy}^{-1}$ to $33.71 \mu \mathrm{Svy}^{-1}$ with a mean value of $15.83 \mu \mathrm{Svy}^{-1}$ and $15.31 \mu \mathrm{Svy}^{-1}$ to $438.17 \mu \mathrm{Svy}^{-1}$ with average of $205.84 \mu \mathrm{Svy}^{-1}$. The rock samples collected in the study are studied to measure the activity of primordial radionuclides such as ${ }^{226} \mathrm{Ra},{ }^{232} \mathrm{Th}$ and ${ }^{40} \mathrm{~K}$ presented in the Table 2. Average activity of primordial radionuclides ${ }^{226} \mathrm{Ra}$, ${ }^{232} \mathrm{Th}$ and ${ }^{40} \mathrm{~K}$ of rock samples ranges from $20 \pm 1.5$ to $150 \pm 3$ $\mathrm{Bqkg}^{-1}, 25 \pm 0$ to $200 \pm 2.5 \mathrm{Bqkg}^{-1}, 450 \pm 4$ to $1800 \pm 15 \mathrm{Bqkg}^{-1}$ respectively. Radon concentration in ground water mainly influenced by local geology of study area [18]. Depending on geology and type of formation of rock the study area is divided into main six zones such as Migmatite Gneiss, Grey granite, Granite, dolerite, Hornblende biotite granite gneiss and Pink Phoriphytic granite locations as shown in the (fig 2). Higher values concentration of radon was found at Singonahalli, Kallahalli, Sannappanahalli, and Yallapura these locations are attributed by Pink Phoriphytic granite. The higher activity of primordial radionuclides have been determined in this rock as given in table2. Kyathsandra, Pandithanahalli, Sira gate, Antharasanahalli these locations are comprised by grey granite. The grey granites contains slightly less activity of primordial radionuclides compared to pink granite. The activity of primordial radio nuclides in rocks also depends upon the mineral composition. The mineral composition of pink granite rock are potassium feldspar followed by Quartz, Sodium Plagioclase, Biotite, Hornblende whereas the mineral composition grey granite is quartz followed by minor amount of mica and amphibole this was observed by elsewhere [19]. The mineral composition of this rock is potassium feldspar it contains higher activity of primordial radio nuclide. Hence we have observe higher activity of primordial radionuclides in pink granite compared to grey granite [20]. In these locations some granite cutting, polishing and crushing work is going on by the industry. The large quantity of fine granite powder produced during the cutting and polishing and this powder conta(A) naturally occurring radioactive materials (NORMS) such as ${ }^{238} \mathrm{U},{ }^{226} \mathrm{Ra}$, and ${ }^{222} \mathrm{Rn}$. To avoid this fine powder in and around the industry continuously water is sprayed on the cutting of granites due to this interaction of water with powder radioactive nuclides are dissolved in water and percolated into the ground. This may also enhance the radium and radon in ground water. Slightly less radon concentration in ground water was found at Kyathsandra, Antharasanahalli, and Hirehalli. These locations are attributed by grey granite as shown in the (fig 2). Lower activity of primordial radionuclides compared to pink granite were found in these rocks presented in Table 2. The mineral composition of pink granite is quartz followed by feldspar with minor amount of mica and amphibole. The major portion of the mineral composition of the grey granite is the quartz which contains lower activity of primordial radioactivity [20]. Hence we observe the lower activity primordial radio activity compared to pink granite. The publics and workers in these locations were receive higher total effective dose due to radon varies from $15.32 \mu \mathrm{Svy}^{-1}$ to 
$438.20 \mu \mathrm{Svy}^{-1}$ with an average value of $205.84 \mu \mathrm{Svy}^{-1}$. The lower concentration of radon in ground water was found at Vasanthanarasapura, oorkere, Lingapura, Ajjagondanahalli, Satyamangala. Hornblende biotite granite gneiss and migmatite gneiss are covered in these areas. The lower activity of primordial radionuclides was found in these rocks was given in Table 2. Migmatite rock is a heterogeneous metamorphic rock having $62 \%$ of silica and $15 \%$ alumina. The maximum mineral composition of this rock is silica it contains lower activity of primordial radionuclides. Vasanthanarasapura industrial area and Ajjagondanahalli attributed by migmatite gneiss these rocks contains lower concentration of primordial nuclides but the radon concentration in ground water of Ajjagondanahalli shows higher than the Vasanthanarasapura industrial area. This is because large quantity of industrial waste was dumped in Ajjagondahalli wastage dump yard. In addition to this large quantity of fine granite powder produced by the cutting and polishing of industries is also dumped in this place. During rainy season large volume of water transports through this waste and interact with it and percolated into the ground. Due to the interaction of water with industrial waste, Naturally occurring radioactive materials (NORMS) and other chemicals in the waste are dissolved in water this may also enhance the radon concentration in ground water and Physico chemical parameter around the Ajjagondanahalli village. Maranayakanapalya belongs to Hirehalli industrial area [21]. These locations are attributed by granite rocks are overlapped by dolerite. The lower activity of primordial radionuclides was found in dolerite, so lower radon concentration were observed as given in the Table 2. Public and workers are received total effective dose due to radon inhalation and ingestion dose by ground water. This study reveals that except 4 all other drinking water samples have radon levels higher than the maximum contaminant level of $11 \mathrm{Bql}^{-1}$ [10]. Maximum contamination level of drinking water due to radon for human consumption is 4 and $40 \mathrm{Bql}^{-1}$ [5]. $71 \%$ water samples from bore wells hand pumps have radon concentrations higher than $40 \mathrm{Bql}^{-1}$ [5]. Recorded readings of radon are compared with recommendations of WHO limit $100 \mathrm{Bql}^{-1}$. It reveals 5 samples of study area are above and rest is below action level. Concentration of radon in ground water of present study area is compared with other studies presented in table 4.

\section{$3.1 \mathrm{pH}$ value}

In addition to concentration of radon in ground water we have measured Physico chemical parameters. This will helps to correlate the concentration of radon in ground water with their physico chemical parametes. The mean values of concentration of radon in water and Physico chemical parameter in ground water are given in the Table 3. The data from the Table 3 shows $\mathrm{pH}$ values of the study area are found to be varies from 6.99 to 7.34 with an average of 7.15. According to the recommendations of the WHO the safe limit of $\mathrm{pH}$ is 7.0-8.5 and as per the recommendations of the
BIS $6.5-8.5$ is the safe limit. The $\mathrm{pH}$ value of the ground water has not crossed safe limit as prescribed by WHO and BIS [11, 22]. And no significant correlation can be observed between concentration of radon and $\mathrm{pH}$ value because radon is an inert gas (Fig.7).

\subsection{Total Dissolved Salts (TDS)}

The quantity of inorganic salts dissolved in water is the TDS value of water. and it indicate the water quality for salinity. All the water samples collected in the study area were analyzed and no sample has crossed the BIS maximum limit $2000 \mathrm{mg} / \mathrm{l}$. High values of TDS impacts the taste, hardness, and corrosive property of water. From fig. 8 it is clear that there is no correlation between radon and TDS[23].

\subsection{Chloride}

Both industrial waste and domestic waste discharges contribute for the chloride in ground water. There are other contributors for the origin of chloride in ground water may be from different sources such as weathering and leaching of sedimentary rocks etc. The amount of chloride in water is an indicator of pollution by sewage. The higher values of the Physico chemical parameter were found at Ajjagondanahalli. This is because the large quantity of industrial wastes produced by the industries are dumped in this place. During rainfall large volume of water transports through this waste. During this transportation the water interacts with waste and some of the chemicals and radio nuclides are dissolved in water and percolate into the ground hence we observe higher chloride content in ground water of this area. The recorded values of Chloride are well within the permissible limit of BIS (fig.3.)

\subsection{Fluoride}

The rocks having fluorspar, fluorite, cryolite, Fluorapatite, and hydroxylopatite are important sources of fluoride in water. The quantity of fluoride in water is mainly influenced by weathering of minerals, rocks dissolution and decomposition containing fluoride over a long time resulting in leaching into ground water [24]. Anthropogenic factors like industrial process contribute for the higher concentration of fluoride into ground water. At Ajjagondanahalli industrial dump yard we are found higher values of fluoride. This may be due to large volume of ground water transport through the industrial waste. During this transportation and interaction of water with the waste and aquifers increased the fluoride concentration in ground water. In the study area fluoride concentration varies from 0.57 to 5.64 with an average of 2.92 the maximum permissible limit of fluoride according to BIS is $1.5 \mathrm{mg} / \mathrm{l}$. except Satyamangala all other water samples shows higher values. Water samples having fluoride content higher than permissible value is not suitable for drinking purpose. We can observe positive correlation between radon and fluoride as shown in fig. 4 


\subsection{Nitrate}

Nitrate concentration observed minimum value of 1.09 and maximum of $58 \mathrm{mg} / \mathrm{l}$ with an average value of 23.34mg/l. According to WHO recommendations and BIS highest permissible value of nitrate in water is $45 \mathrm{mg} / \mathrm{l}$. In our study area only one sample collected at Ajjagondanahalli industrial area has exceed the permissible limit. The higher concentration in ground water was observed in this area because of the effluents discharged by industries, usage of fertilizers and chemicals for agriculture, seepage and sileage through drainage system contributes for higher nitrate concentration. As per the data no correlation can be drawn between concentrations of radon in water with concentration of nitrate (Fig.5). High nitrate has been observed in Ajjagondanahalli and other places this may be due to the chemical fertilizer from cultivated land and industrial drainage from domestic and industrial water [25].

\subsection{Sulphate}

Sulphate concentration in the study area ranges between $33.8 \mathrm{mg} / \mathrm{l}$ to $299 \mathrm{mg} / \mathrm{l}$ with an average value of $85.12 \mathrm{mg} / \mathrm{l}$. In all the samples Sulphate concentration in the study area is below the acceptable limit as recommended by BIS of $400 \mathrm{mg} / \mathrm{l}$. In some locations like Maranayakanapalya and singonahalli there is negative correlation between concentration of radon and sulphate [26] (Fig.6)

\subsection{Electrical conductivity}

It is the capacity of water to conduct electrical current. This depends on three factors i.e. ions mobility, temperature and ions present in water. Electrical conductivity of water is determined by the dissolved salts [27]. Samples collected in the study area show the values ranging from 596 to 1050 $\mu \mathrm{SCm}^{-1}$ with an average of $781.77 \mu \mathrm{SCm}^{-1}$ (Fig.9). Ajjagondanahalli, Lingapura and Pandithanahalli water samples shows higher values of electrical conductivity as BIS recommended maximum permissible value of $1000 \mu \mathrm{SCm}^{-1}$.

\section{CONCLUSION}

The average concentration of radon in ground water of the study area varies from $5.61 \mathrm{Bql}^{-1}$ to $160.50 \mathrm{Bql}^{-1}$ with an average value of $75.40 \mathrm{Bql}^{-1}$. Slightly higher total effective doses compared to global average are received by publics and workers of the study area. The type of aquifers is the most deciding factor for the concentration of radon in ground water. The locations attributed by pink granite shows higher radon concentration in ground water and the rocks of the areas shows higher value of primordial radionuclides [10-11] The industrial activity is influences the increased the radon concentration in ground water and physicochemical parameters. The concentration of radon in ground water and activity of primordial nuclides of different rock samples of the study area are comparable to global average.

\section{REFERENCES}

[1]. Teng, Y., Yang, J., Zuo, R., \& Wang, J. (2011). Impact of urbanization and Industrialization upon surface water quality: A pilot study of Panzhihua mining town. Journal of earth science, 22(5), 658.

[2]. Rajaram, T., \& Das, A. (2008). Water pollution by industrial effluents in India: discharge scenarios and case for participatory ecosystem specific local regulation. Futures, 40(1), 5669.

[3]. Buddemeier, R. W., \& Hunt, J. R. (1988). Transport of colloidal contaminants in groundwater: radionuclide migration at the Nevada Test Site. Applied geochemistry, 3(5), 535-548.

[4]. Iyengar, M. A. R. (1990). The natural distribution of radium. The environmental behavior of radium, 1, 59-128.

[5]. United Nations. Scientific Committee on the Effects of Atomic Radiation. (2008). Effects of ionizing radiation: UNSCEAR 2006 Report to the General Assembly, with scientific annexes (Vol. 2). United Nations publications.

[6]. Cantor, K. P. (1997). Drinking water and cancer. Cancer Causes \& Control, 8(3), 292-308.

[7]. BEIR, VII (2005). Health risks from exposure to low levels of ionizing radiation. The National Academies report in brief.

[8]. International Agency for Research on Cancer. (2001). Ionizing Radiation: Some Internally Deposited Radionuclides. International Agency for Research on Cancer.

[9]. Lubin, J. H., Boice Jr, J. D., Edling, C., Hornung, R. W., Howe, G. R., Kunz, E., ... \&Tirmarche, M. (1995). Lung cancer in radon-exposed miners and estimation of risk from indoor exposure. JNCI: Journal of the National Cancer Institute, 87(11), 817-827.

[10]. USEPA (1991). National primary drinking water regulations; radionuclides: proposed rule. U.S. Government Printing Office (1991) United States Environmental Protection Agency.

[11]. WHO (2008). Guidelines for Drinking-water: incorporating 1st and 2nd addenda,Vol. 1, Recommendations. World Health Organization, 2008.

[12]. Raghavayya, M., Iyengar, M., \&Markose, P. M. (1980). Estimation of Ra-226 by emanometry. Bulletin of Radiation Protection, 3, 5.

[13]. Srinivasa E, Rangaswamy D, Suresh S, Nagabhushana, S R, Sannappa J, \&Umehsareddy, (2018). Measurement of radon concentration in drinking water and estimation of radiation dose to the publics of Hassan city, Karnataka, India. Radiation Protection and Environment vol 41, issue 3, p132-135

[14]. IAEA (1989) Regional work on environmental sampling and measurement of radioactivity for monitoring purposes. Journal of Environmental radioactivity, 9, 163-180

[15]. Covello, V. T., \&Merkhoher, M. W. (2013). Risk assessment methods: approaches for assessing health and environmental risks. Springer Science \& Business Media.

[16]. Sannappa, J., Chandrashekara, M. S., Sathish, L. A., Paramesh, L., \&Venkataramaiah, P. (2003). Study of background radiation dose in Mysore city, Karnataka State, India. Radiation measurements, 37(1), 55-65.

[17]. Singh, S., Rani, A., \& Mahajan, R. K. (2005). ${ }^{226}$ Ra, ${ }^{232}$ Th and ${ }^{40} \mathrm{~K}$ analysis in soil samples from some areas of Punjab and Himachal Pradesh, India using gamma ray spectrometry. Radiation measurements, 39(4), 431-439.

[18]. Ramola, R. C., Gusain, G. S., Badoni, M., Prasad, Y., Prasad, G., \& Ramachandran, T. V. (2008). ${ }^{226} \mathrm{Ra},{ }^{232} \mathrm{Th}$ and ${ }^{40} \mathrm{~K}$ contents in soil samples from Garhwal Himalaya, India, and its radiological implications. Journal of Radiological Protection, 28(3), 379. 
[19]. Sannappa, J., Ningappa, C., \&Narasimha, K. N. (2010). Natural radioactivity levels in granite regions of Karnataka State.

[20]. Ningappa C., Sannappa J \&Karunakara N (2008). Study on radionuclides in granite quarries of Bangalore rural district, Karnataka, India. Radiation protection dosimetry. 131(4): 495502.

[21]. Nagabhushana, S. R., Sannappa, J., Rangaswamy, D. R., \& Srinivasa, E. (2018). Study on Radon and Thoron Levels in and Around Different Industries of Tumkur and Bangalore Districts. Materials Today: Proceedings, 5(10), 22712-22717.

[22]. B. I. S. (2012). Indian Standard Drinking Water-Specification (Second revision). Bureau of Indian Standards (BIS), New Delhi.

[23]. Popkin, B. M., Armstrong, L. E., Bray, G. M., Caballero, B., Frei, B., \& Willett, W. C. (2006). A new proposed guidance

\section{AUTHORS PROFILE}

Mr. S.R. Nagabhushana M.Sc M.Phil.was born in Sompura,

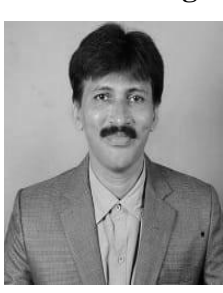
Koratagere Taluk, Tumkur Distt. Karnataka. $\mathrm{He}$ is currently working as Assistant Professor in Department of physics Govt. first grade college Tiptur Karnataka India since 2009. He is pursuing Ph.D from Kuvempu University, Karnataka. He has published 4 research papers in reputed National and international journals also presented his research works in conferences and symposia. His main research work focuses on natural radioactivity. He has 15 years of teaching experience and 8 years of research experience. He is Life member of NTSI since 2011.

Dr. Srinivasa. E was born in Mallenahally gokula Village, Madhugiri Taluk, Tumkur district, Karnataka, in 1971. He received the B.Sc degree from the University of Bangalore, in 1992 and M.Sc. degree from the same University in 1994 and M.Phil degree in Physics from Periyar University,Tamil Nadu, in 2007 and $\mathrm{Ph} . \mathrm{D}$. degree from Kuvempu University, Shimoga in 2017.He has 22 years of teaching experience as Lecturer and Assistant professor. He has 9 years of Research experience. He is currently working has ASSISTANT PROFESSOR of Physics at I.D.S.G GOVERNMENT COLLEGE CHICKMAGALUR. He is the author of more than 16 articles in reputed National and international journals, 9 articles in conference proceedings and he has presented more than 15 research articles in national and international seminars/conferences.His research interests include Environmental Radioactivity, Radon-Thoron related areas and Radiation Physics. He was the life member of Indian Association for Physics Teachers (IAPT).

Dr. J. Sannappa was born in Erabally Gollarahatty, Hiriyur Taluk, Chitradurga district. He received his Master degree (M. system for beverage consumption in the United States.The American journal of clinical nutrition, 83(3), 529-542.

[24]. Edmunds, W. M., \& Smedley, P. L. (2013). Fluoride in natural waters. In Essentials of medical geology (pp. 311-336).

[25]. Srilatha, M. C., Rangaswamy, D. R., \& Sannappa, J. (2014). Studies on concentration of radon and physicochemical parameters in ground water around Ramanagara and Tumkur districts, Karnataka, India. Int J AdvSci Tech Res, 2(4), 641-660.

[26]. Miao, Z., Carroll, K. C., \&Brusseau, M. L. (2013). Characterization and quantification of groundwater sulfate sources at a mining site in an arid climate: The Monument Valley site in Arizona, USA. Journal of hydrology, 504, 207215.

[27]. Domenico, P. A., \& Schwartz, F. W. (1998). Physical and chemical hydrogeology (Vol. 506). New York: Wiley.

Sc) in Physics from University of Mysore in 1985 and Ph.D.,

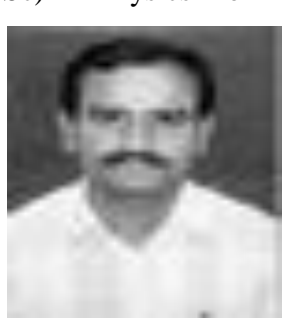
degree from University of Mysore in 2001.

He has 28 years of teaching experience as Lecturer and assistant professor. And he has 23 years of Research experience. $\mathrm{He}$ is currently working has Professor in Department of Studies and Research in Physics, Kuvempu University, Shimoga. $\mathrm{He}$ is the author of more than 100 articles in reputed National and international journals and he was presented more than 80 research articles in national and international seminars/conferences. His area of interest is Environmental Radioactivity, RadonThoron related areas, Nuclear Physics, Polymer physics, Chemical physics.

Dr. J. Sannappa was the life member of Indian Society for Radiation Physics (ISRP), Nuclear Track Society of India (NTSI), International Nuclear Track Society (INTS), International Science Congress Association (ISCA) and Karnataka state Videshi Vignana Andolana.

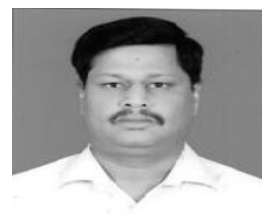

Mr. Suresh S , Head of the Dept. of Physics at M.P.E Society's ,S.D.M Degree College Honnavar ,Uttara Kannada District, Karnataka Has been teaching physics since 1994 . He obtained his masters degree in physics in 1994 from Kuvempu University, M.Phil degree in 2008 from Alagappa University, Tamilnadu. He is Pursuing Ph.D from Kuvempu University, Shimoga,Karnataka. He has five years of Research experience in the field of Environmental Radioactivity. He is Life member of IAPT. 
Fig.1. Radon bubbler

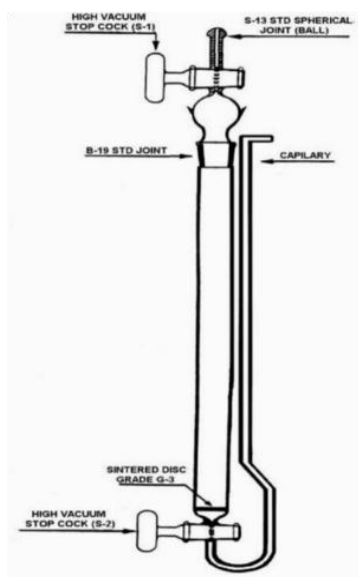

Fig.2 . Geological map Tumkur industrial areas

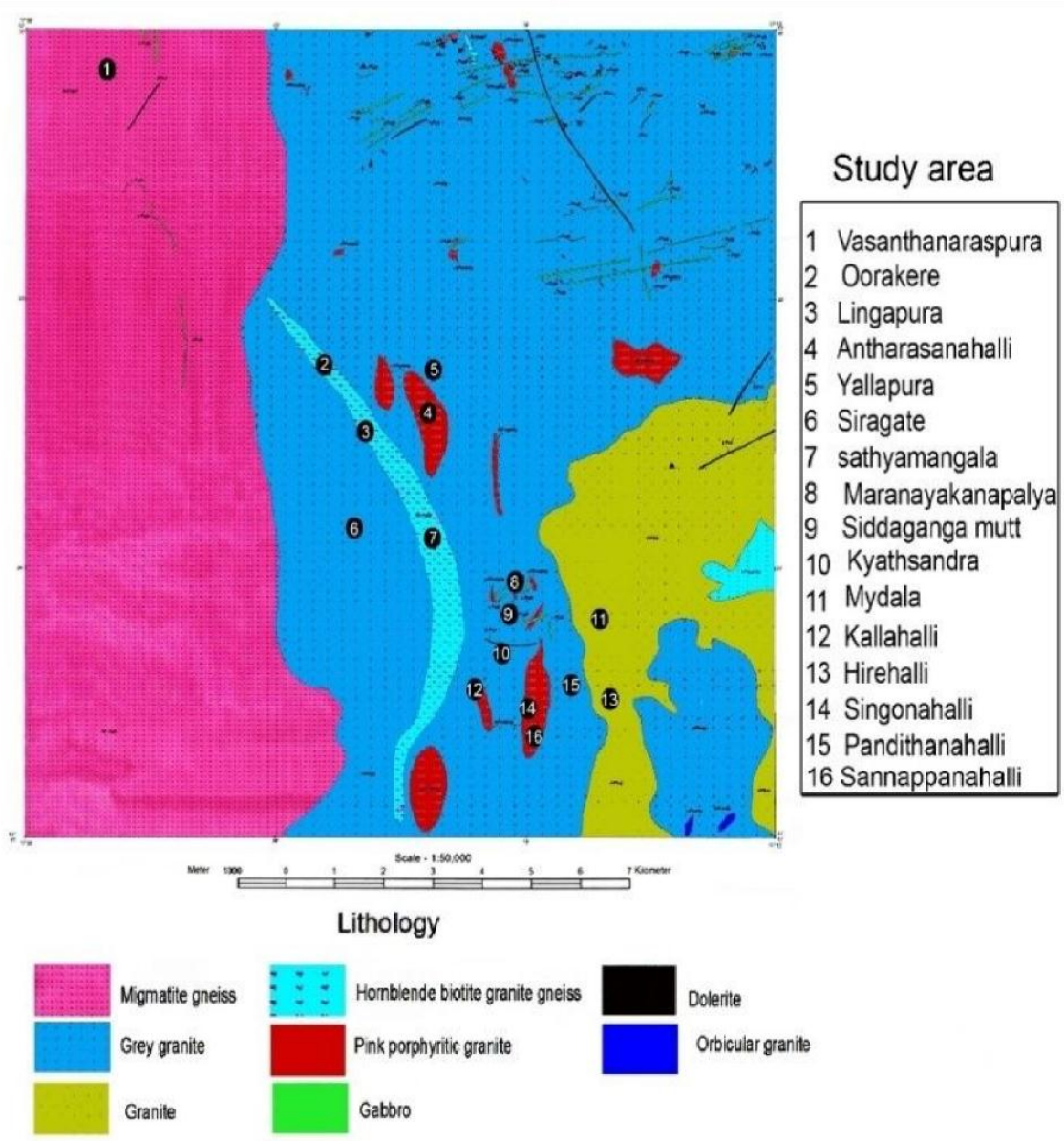




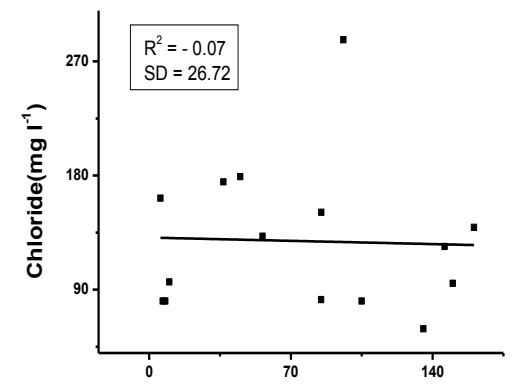

${ }^{222} \mathrm{Rn}$ concentration $\left(\mathrm{Bq}^{-1}\right)$

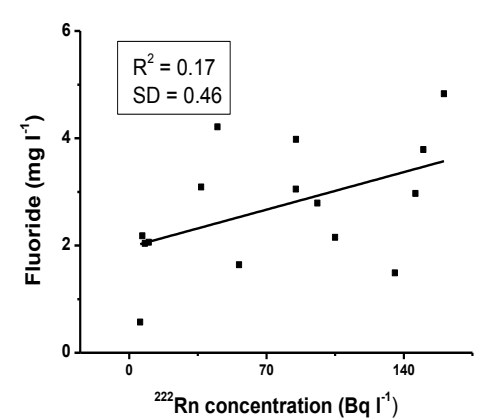

Fig.3 Radon activity concentration versus Chloride Fig.4 Radon activity concentration versus Fluoride

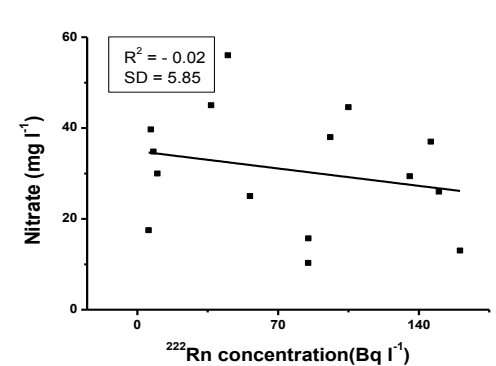

Fig.5. Radon activity concentration versus Nitrate

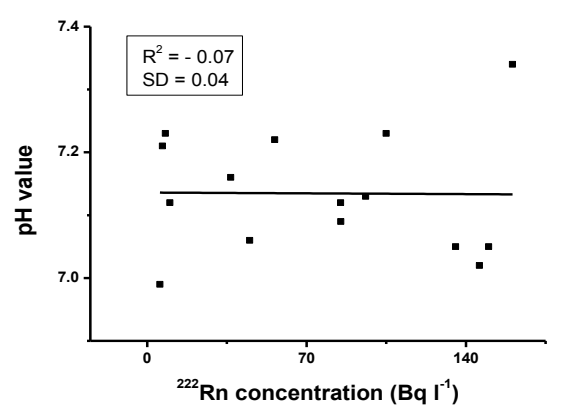

Fig 7. Radon activity concentration versus $\mathrm{pH}$

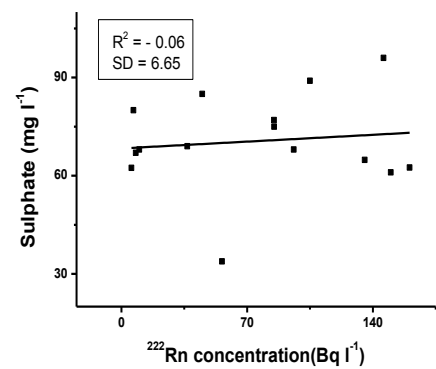

Fig.6 Radon activity concentration versus Sulphate

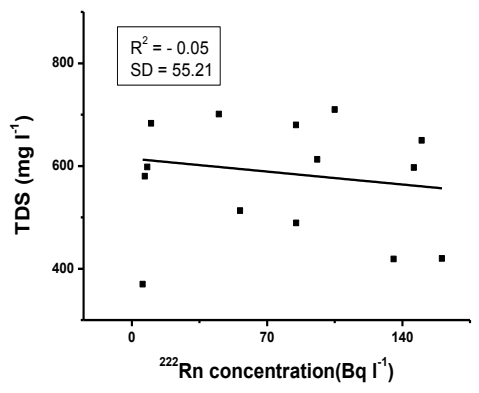

Fig. 8 Radon activity concentration versus TDS

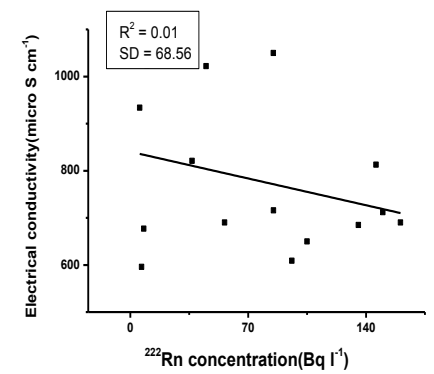

Fig. 9 Radon activity conc. versus Electrical Conductivity 
Table 1.Annual effective dose due to radon in ground water of working places of Tumkur industrial areas

\begin{tabular}{|c|c|c|c|c|c|c|c|c|}
\hline Location & Geology of Area & Type of Industries & $\begin{array}{l}{ }^{222} \mathrm{Rn} \\
\left(\mathrm{Bql}^{-1}\right)\end{array}$ & $\begin{array}{l}\text { Inhalation } \\
\left(\mu \operatorname{Svy}^{-1}\right)\end{array}$ & $\begin{array}{l}\text { Ingestion } \\
\left(\mu \mathrm{Svy}^{-1}\right)\end{array}$ & $\begin{array}{l}\text { Lung } \\
\left(\mu \operatorname{Svy}^{-1}\right)\end{array}$ & $\begin{array}{l}\text { Stomach } \\
\left(\mu \mathrm{Svy}^{-1}\right)\end{array}$ & $\begin{array}{r}\text { Total dose } \\
\left(\mu \mathrm{Svy}^{-1}\right)\end{array}$ \\
\hline \multicolumn{9}{|c|}{ 1.Vasanthanarasapura industrial area } \\
\hline Vasanthanarasapura & $\begin{array}{l}\text { Migmatite } \\
\text { Gneiss }\end{array}$ & $\begin{array}{l}\text { Cement block, Oil } \\
\text { refineries, Steel } \\
\text { Industries, } \\
\text { Roofing sheets }\end{array}$ & $8 \pm 1$ & 20.16 & 1.68 & 2.419 & 0.202 & 21.84 \\
\hline Ajjagondanahalli & $\begin{array}{c}\text { Migmatite } \\
\text { Gneiss }\end{array}$ & $\begin{array}{c}\text { Wastage dumping } \\
\text { yard }\end{array}$ & $45 \pm 5$ & 113.4 & 9.45 & 13.61 & 1.134 & 122.85 \\
\hline \multicolumn{9}{|c|}{ 2.Antharasanahalli industrial area } \\
\hline Antharasanahalli & Grey granite & $\begin{array}{c}\text { Rice mill, Oil } \\
\text { refineries, Granite } \\
\text { cutting \& } \\
\text { Polishing }\end{array}$ & $56 \pm 2$ & 141.1 & 11.76 & 16.93 & 1.411 & 152.88 \\
\hline Lingapura & Hornblend & Rice mill & $9.96 \pm 3$ & 25.1 & 2.092 & 3.012 & 0.251 & 27.191 \\
\hline Oorkere & Hornblend & Tiles industries & $6.69 \pm 1$ & 16.86 & 1.405 & 2.023 & 0.169 & 18.264 \\
\hline Yallapura & $\begin{array}{c}\text { Pink Phoriphytic } \\
\text { granite }\end{array}$ & Stone crushing & $135.5 \pm 4$ & 341.5 & 28.46 & 40.98 & 3.415 & 369.92 \\
\hline Siragate & Grey granite & Brick industries & $85.04 \pm 3$ & 214.3 & 17.86 & 25.72 & 2.143 & 232.16 \\
\hline $\begin{array}{l}\text { 3.Satymangala } \\
\text { industrial area }\end{array}$ & $\begin{array}{c}\text { Hornblend } \\
\text { Biotite Gneiss }\end{array}$ & $\begin{array}{l}\text { Medicine } \\
\text { production }\end{array}$ & $5.61 \pm 1$ & 14.14 & 1.178 & 1.696 & 0.141 & 15.315 \\
\hline \multicolumn{9}{|c|}{ 4.Hirehalli industrial area } \\
\hline Hirehalli & Granite & $\begin{array}{l}\text { Granite cutting } \\
\text { \&polishing }\end{array}$ & $96 \pm 6$ & $\begin{array}{l}241.9 \\
92.43\end{array}$ & $\begin{array}{l}20.16 \\
7.703\end{array}$ & $\begin{array}{l}29.03 \\
11.09\end{array}$ & $\begin{array}{l}2.419 \\
0.924\end{array}$ & $\begin{array}{l}262.08 \\
100.14\end{array}$ \\
\hline Maranayalanapalya & Dolerite & Stone crushing & $36.68 \pm 4$ & 404.5 & 33.71 & 48.54 & 4.045 & 438.17 \\
\hline Singonahalli & $\begin{array}{l}\text { Pink Phoriphytic } \\
\text { granite }\end{array}$ & $\begin{array}{l}\text { Copper industries, } \\
\text { Granite cutting } \\
\text { \&polishing }\end{array}$ & $160.5 \pm 8$ & 241.9 & 20.16 & 29.03 & 2.419 & 262.08 \\
\hline Pandithanahalli & Grey granite & Cement bricks & $85 \pm 5$ & 214.2 & 17.85 & 25.7 & 2.142 & 232.05 \\
\hline Kyathasandra & Grey granite & Sand Bricks & $105 \pm 6$ & 264.6 & 22.05 & 31.75 & 2.646 & 286.65 \\
\hline Kallahalli & $\begin{array}{c}\text { Pink Phoriphytic } \\
\text { granite }\end{array}$ & Stone crushers & $150 \pm 4$ & 378 & 31.5 & 45.36 & 3.78 & 409.5 \\
\hline Sannappanahalli & $\begin{array}{l}\text { Pink Phoriphytic } \\
\text { granite }\end{array}$ & $\begin{array}{c}\text { Cement blocks, } \\
\text { stone crushing and } \\
\text { powdering }\end{array}$ & $146 \pm 5$ & 367.9 & 30.66 & 44.15 & 3.679 & 398.58 \\
\hline \multicolumn{3}{|c|}{ MINIMUM } & $5.61 \pm 1$ & 14.14 & 1.18 & 1.69 & 0.141 & 15.31 \\
\hline \multicolumn{3}{|c|}{ MAXIMUM } & $160.5 \pm 8$ & 404.50 & 33.71 & 48.54 & 4.045 & 438.17 \\
\hline \multicolumn{3}{|c|}{ MEAN VALUE } & $67.54 \pm 4$ & 190 & 15.83 & 22.80 & 1.90 & 205.84 \\
\hline
\end{tabular}


Table 2. Activity of radionuclides in different locations of the study area

\begin{tabular}{|c|l|l|l|l|}
\hline \multirow{2}{*}{$\begin{array}{c}\text { Sl. } \\
\text { no. }\end{array}$} & \multirow{2}{*}{ Type of rock } & \multicolumn{3}{|c|}{ Activity of radionuclide $\left(\mathrm{Bqkg}^{-1}\right)$} \\
\cline { 3 - 5 } & & Ra-226 & Th-232 & $\mathrm{K}-40$ \\
\hline 1. & Pink Granite & $150 \pm 3$ & $200 \pm 2.5$ & $1800 \pm 15$ \\
\hline 2. & Dolerite Granite & $25 \pm 1.2$ & $29 \pm 1.5$ & $500 \pm 5$ \\
\hline 3. & Grey Granite & $50 \pm 0.8$ & $125 \pm 0.4$ & $1320 \pm 18$ \\
\hline 4. & Granite Genesis & $85 \pm 2$ & $158 \pm 2.5$ & $201 \pm 8$ \\
\hline 5. & Migmatite Gneiss & $20 \pm 1.5$ & $35 \pm 2.2$ & $450 \pm 4$ \\
\hline 6. & Minimum & $20 \pm 1.5$ & $25 \pm 0.4$ & $450 \pm 4$ \\
\hline 7. & Maximum & $150 \pm 3$ & $200 \pm 2.5$ & $1800 \pm 15$ \\
\hline 8. & Mean Value & $65.6 \pm 1.3$ & $81.8 \pm 1.5$ & $854.2 \pm 12$ \\
\hline
\end{tabular}

Table 3. Physicochemical Parameters

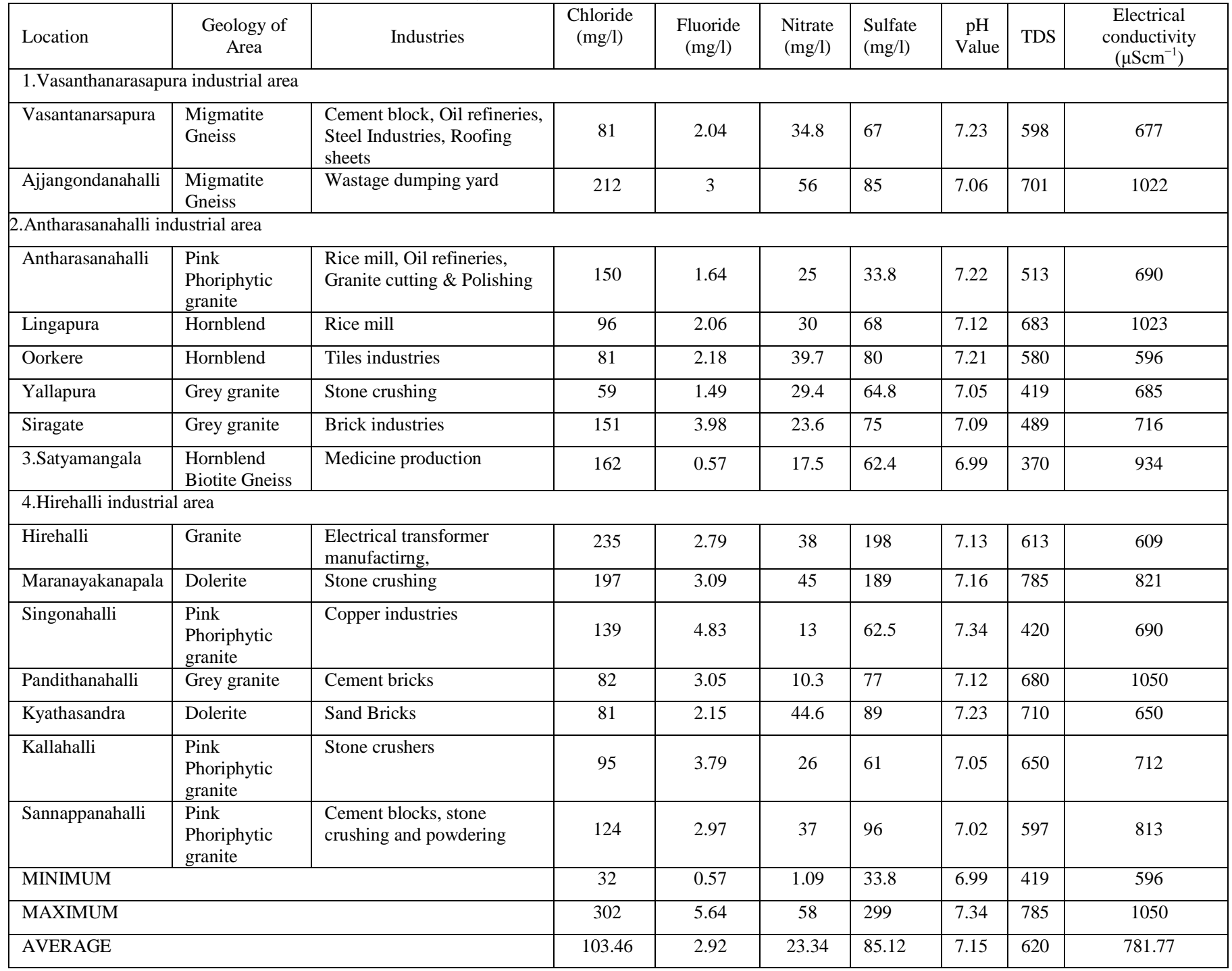


Table.4. Comparison of radon concentration in groundwater with those reported by the other investigators in different parts of the world.

\begin{tabular}{|l|c|l|}
\hline Region & $\begin{array}{c}\text { Literature value } \\
\text { range }\left(\mathrm{Bq}^{-1} \text { ) }\right.\end{array}$ & Reference \\
\hline Greece & $0.8-24$ & (Marzougui, Hamzaoui, Farah, \& Ben Nessib 2008) \\
\hline Pakistan & $2.0-2.9$ & (Manzoor, Alaamer, \& Tahir 2008) \\
\hline Rajasthan, India & $1.6-5.4$ & (Rani, Mehra, \& Duggal, 2012) \\
\hline Punjab, India & $0.9-5.1$ & (Duggal, Mehra, \& Rani, 2013) \\
\hline $\begin{array}{l}\text { Mysore region, } \\
\text { Karnataka }\end{array}$ & $4.25-435$ & (Chandrashekara, Veda, \&Paramesh, 2011) \\
\hline Kolar, Karnataka & $3.38-122.89$ & (Reddy,Ningapa, Sannappa, Rangswamy, \& Srinivasa, 2017) \\
\hline $\begin{array}{l}\text { Hassan district, } \\
\text { Karnataka }\end{array}$ & $0.85-60.74$ & (Srinivasa, Rangaswamy, \& Sannappa, 2015) \\
\hline $\begin{array}{l}\text { Bangalore, } \\
\text { Karnataka }\end{array}$ & $55.96-1189.30$ & (Hunse, Najeeb, Rajarajan, \&Muthukkannan, 2010) \\
\hline $\begin{array}{l}\text { NRPura and } \\
\text { Koppa, Karnataka }\end{array}$ & $3.56-90.63$ & (Srinivasa, Rangaswamy, Suresh, Reddy \& Sannappa, 2018). \\
\hline $\begin{array}{l}\text { Present study } \\
5.61-160.50\end{array}$ & \\
\hline
\end{tabular}

